\title{
"Current status and prospects of development of the system of agrarian insurance in Ukraine"
}

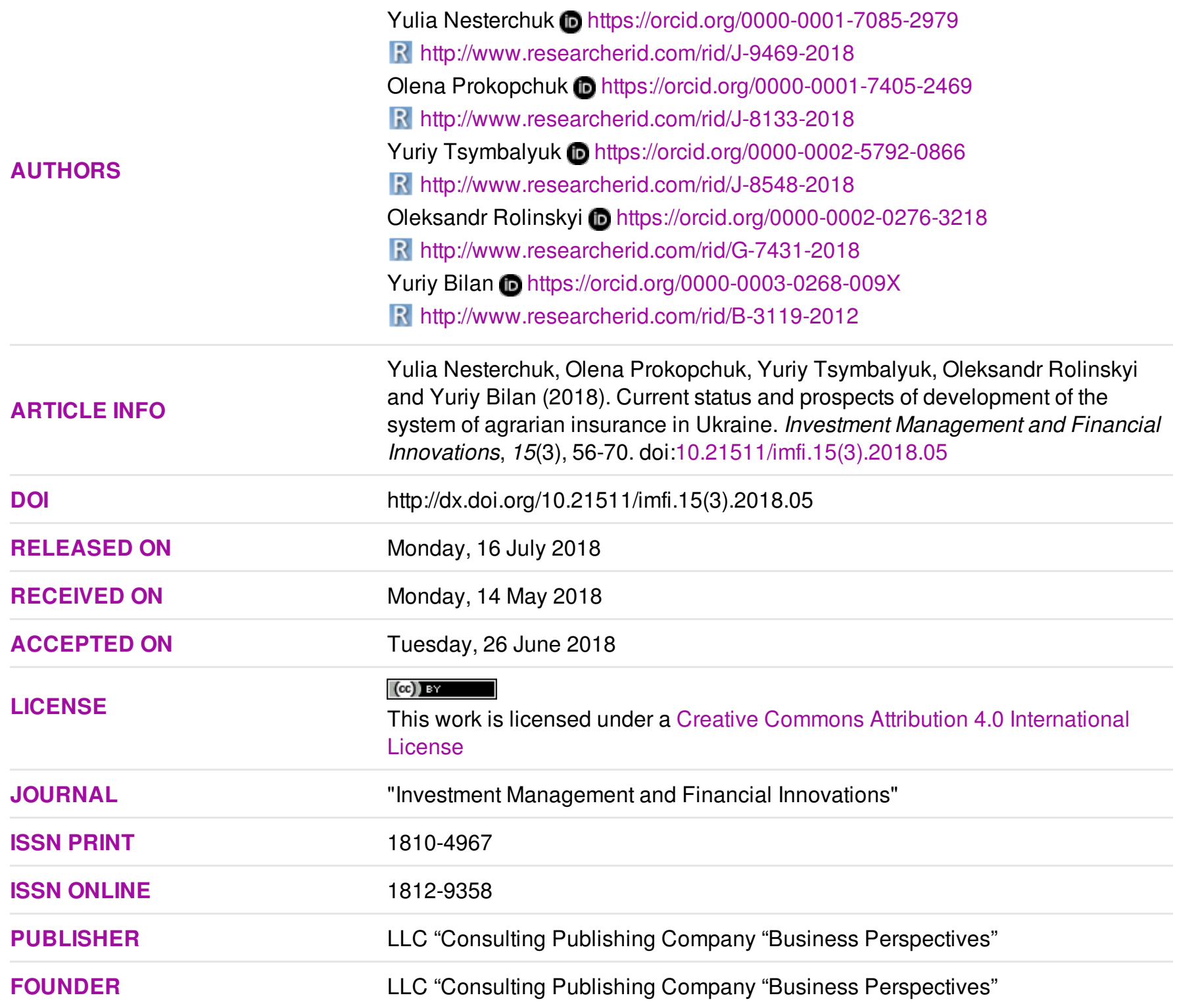

NUMBER OF REFERENCES

29
NUMBER OF FIGURES

11
NUMBER OF TABLES

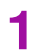

(C) The author(s) 2022. This publication is an open access article. 


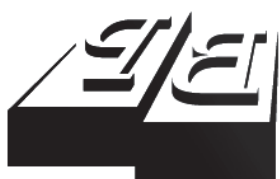

BUSINESS PERSPECTIVES



LLC "CPC "Business Perspectives" Hryhorii Skovoroda lane, 10, Sumy, 40022, Ukraine

www.businessperspectives.org

Received on: $14^{\text {th }}$ of May, 2018 Accepted on: $26^{\text {th }}$ of June, 2018

(C) Yulia Nesterchuk,

Olena Prokopchuk, Yuriy

Tsymbalyuk, Oleksandr Rolinskyi, Yuriy Bilan, 2018

Yulia Nesterchuk, Doctor of Economics, Professor, Dean of Faculty of Economics and Entrepreneurship, Uman National University of Horticulture, Ukraine.

Olena Prokopchuk, Ph.D. in Economics, Associate Professor, Associate Professor of Department of Finances, Banking and Insurance, Uman National University of Horticulture, Ukraine.

Yuriy Tsymbalyuk, Ph.D. in Economics, Associate Professor, Associate Professor of Department of Marketing, Uman National University of Horticulture, Ukraine.

Oleksandr Rolinskyi, Ph.D. in Economics, Associate Professor, Associate Professor of Department of Finances, Banking and Insurance, Uman National University of Horticulture, Ukraine.

Yuriy Bilan, Doctor of Economics, Associate Professor, Associate Professor of Department of Human Resources Management and Development, Trencin University of Alexander Dubcek in Trencin, Slovakia.

\section{(ㄷ) (i)}

This is an Open Access article, distributed under the terms of the Creative Commons Attribution 4.0 International license, which permits unrestricted re-use, distribution, and reproduction in any medium, provided the original work is properly cited.
Yulia Nesterchuk (Ukraine), Olena Prokopchuk (Ukraine), Yuriy Tsymbalyuk (Ukraine), Oleksandr Rolinskyi (Ukraine), Yuriy Bilan (Slovakia)

\section{CURRENT STATUS AND PROSPECTS OF DEVELOPMENT OF THE SYSTEM OF AGRARIAN INSURANCE IN UKRAINE}

\begin{abstract}
Under the conditions of the development of market relations, the insurance protection of agricultural producers plays an essential role in the economic stabilization of their development. Insurance can be one of the most effective tools for managing production, market and legal risks, but agricultural insurance is not well developed in the country. The purpose of the article is to study the current state and prospects for further development of the Ukrainian agrarian insurance system, based on developing the strategy of development of the latter with maximum consideration of needs and interests of all its participants.
\end{abstract}

General scientific methods of scientific knowledge and research of economic phenomena are used for the achievement of the goal set in the article, such as the abstract-logical method, comparison method, monographic method, tabular method, graphical and scientific generalization.

The article investigates features of the present state and general tendencies of functioning of the Ukrainian agrarian insurance system and outlines general features and prospects of further development of the latter, which are based on development of the strategy of system development with maximum consideration of needs and interests of all its participants. A set of principles is defined on which the strategy of development of the Ukrainian agricultural insurance system should be based and their further functioning in the format of the model of private-public partnership is proposed within the framework of the developed strategy. This represents a balance between public-private partnerships. The results of the study can be used for further scientific developments in this direction. The implementation of the measures proposed in the framework of the strategy for the development of the Ukrainian agrarian insurance system through the effective use of state resources and maximum use of the agrarian market and the insurance market should ensure stability of both agricultural production in general and income of the rural population in particular. This is a prerequisite for stable economic growth of the country and an increase in the welfare of its citizens.

\section{Keywords}

agricultural insurance, insurance protection, risks, state support, insurance products, insurance companies, agricultural producers

\section{JEL Classification G22, G28, Q13, Q18}

\section{INTRODUCTION}

The agricultural production sector is distinguished by a number of specific features among all other branches of production. One of them is the direct dependence on natural disasters and weather and climatic conditions as a result of which the enterprises are in constant high risks, which have a significant impact on the indicators of production. With the help of agricultural insurance as one of the most effective risk management tools, it is possible to combine interests of key players in the agrarian insurance market and the state. However, at this stage, the Ukrainian agricultural insurance market is at the stage of development, which is evidently confirmed by the accelerated pace of development of the domestic agricultural sector and constant insignificant volumes of insured products. This leads to the fact that only about $3 \%$ of all sown areas are insured. 


\section{THEORETICAL BASIS}

Insurance protection in the agrarian sector of the Ukrainian economy is essential because, as a rule, agricultural producers have significant losses as a result of unfavorable weather conditions (Polchanov, 2013). That is why such an important tool as agricultural insurance can help agricultural producers to minimize losses caused by adverse weather conditions and enable them to pay off their debt obligations, in particular for loans (Sakhno, 2010; Prokopchuk, 2017). This time span is characterized by the development and establishment of agricultural insurance in Ukraine. A number of domestic scientists in their works investigated peculiarities of functioning of the Ukrainian market of agricultural insurance services (Sakhno, 2010; Polchanov, 2013; Prokopchuk, 2017; Navrotskyi, 2012). An important issue in the writings of scientists is the study of the role of the state and the need for state support in the field of insurance of agricultural products (Martseniuk-Rozaronova, 2010; Nedbaieva, 2009; Sholoiko, 2013).

Ukraine's belonging to the risky agricultural area is largely due to the dependence of the agricultural producers' performance on the influence of weather factors. The effects of global climate change are becoming increasingly tangible in Ukraine (Prokopchuk, 2017). In many regions, rising temperatures and droughts may become factors that ultimately limit the productivity of agriculture, one of the most important sectors of the Ukrainian economy (p. 87). As a result, a large number of agricultural producers can simultaneously suffer from such a systemic risk.

The impact of weather risks on the results of productive activities of agrarians is only increasing from year to year. The climate change leads to more frequent and more intense manifestations of extreme weather conditions as heavy rainfall, droughts and hurricanes (Mentel \& Brożyna, 2015). In the last decade, a number of natural disasters in the world have multiplied several times, bringing many billions of losses to the agrarian sector (p. 53). The international practice testifies to the necessity of developing effective models of agrarian risk insurance in the form of private-public partnership (p. 55). In this context, it should be noted that in the world practice, three key models of state regulation of insurance protection in the agrarian sector of the economy are applied: a model of state regulation, characterized by the maximum participation of the state; a model of public-private partnership and a market model in which the participation of the state is minimal.

The experience of developed countries in preventing such losses is to a large extent related to agricultural insurance. Such countries as Canada, the United States and Spain as flagships in the field of agricultural insurance have introduced insurance schemes that allow farmers to protect effectively their crops from the weather risks (Shen \& Odening, 2013; Panda, 2013). Although insurance in these countries is entirely voluntary, the state induces farmers to use insurance through the possibility of receiving subsidies for the cultivation of certain crops. Thanks to such stimulation, 50\%$80 \%$ of crops are annually insured in these countries (Takahashi, Ikegami, Sheahan, \& Barrett, 2016).

A number of scientists share the view that an important aspect of risk assessment is not only its identification, but also the development of measures for its leveling or reduction (Nedbaieva, 2009). Modern scholars and practitioners point out that the most effective tool for risk management in agriculture is insurance providing a system of economic relations to protect property interests of individuals and legal entities in certain events (Ulianych \& Bechko, 2014).

Works of foreign scientists are devoted to a very wide range of issues related to the implementation of insurance activities in the agricultural sector of the economy. Much of this is related to the study of insurance products offered in agricultural insurance markets of different countries. This issue is considered by foreign scientists in the context of key insurance products: classical (traditional) - in the context of mono and multi risk types, index and specific ones (income insurance) (Kenderdine, 2018).

So, in their studies, Fuchs and Wolff (2011), Mclntosh et al. (2013), Meza et al. (2008), Sarris (2013), Shi and Jiang (2016) showed features of insurance index schemes, in particular, feasibility and promise of using weather index insurance 
products. Foreign scientists have discussed in detail problems and prospects of insurance index schemes in the agrarian sector of the economy in their works (Bogale, 2015).

In this context, it should be noted that index insurance products have become widespread in the foreign practice, while in the domestic one, they are only at the stage of development and implementation within the framework of pilot projects (Streimikiene, Balezentis, \& Krisciukaitiene, 2016). Such kind of index insurance products is offered for the agrarian sector of the economy as insurance based on weather indices (temperature, precipitation, wind force, etc.), insurance based on regional yield index and insurance based on regional income index (yield and product prices) (p. 62).

Works of Ahmed and Serra (2014), Müller et al. (2017), Enjolras and Sentis (2011) are devoted to the study of general problems in the field of agricultural insurance.

Articles of Ahsan et al. (1982) raise the issue of implementing effective agricultural insurance in developed countries.

At the same time, despite a large number of publications by both domestic and foreign scientists, at this stage, the Ukrainian agricultural insurance market overcomes the difficult path of formation and development and functions in the absence of a strategy for the development of the latter, the resource that was previously has expired and requires an urgent update. The foregoing determines the need to strengthen further research in this direction.

General scientific methods of scientific knowledge and research of economic phenomena are used for the achievement of the goal set in the article. Basically, the theoretical and methodological basis of the research is works of domestic scientists and practitioners, as well as foreign scientists involved in researching the market of agricultural insurance services in general and issues of developing an effective Ukrainian agrarian insurance system in particular. In the article, such methods as the abstract-logical method, comparison method, monographic method, tabular method, graphical and scientific generalization are used.
The purpose of the article is to study the current state and prospects for further development of the Ukrainian agrarian insurance system, based on developing the strategy of development of the latter with maximum consideration of needs and interests of all its participants.

\section{RESULTS}

\subsection{Modern trends in the agrarian sector of the Ukrainian economy}

For Ukraine, the agricultural production sector has always been one of the priority areas from the point of view of both foreign economic and domestic economic development of the country, since the urgency of issues on organization, production and support of food supply is acute for each state in all periods of development. This statement is decisive not only for ensuring viability and self-sufficiency of the country as a whole and society in particular, but also multitude of the most diverse areas of human activity.

In most countries where agriculture is developing successfully (for example, USA, Canada, Spain and China), the agricultural insurance industry is at a high level. That is, the key rule of the international practice is the dependence of success of the agricultural development on successful functioning of the agricultural insurance market. As an exception to this statement, there are two countries (Brazil and Ukraine) in which a strong development of the agricultural and industrial complex is accompanied by an underdeveloped agricultural insurance tool.

It should be noted that domestic agriculture has maintained leadership in the national economy for many years and, therefore, has a significant impact on filling state budget and, ultimately, on living standards of the population.

Features of the agricultural production in terms of crop and livestock sectors and its share in GDP of Ukraine are shown in Figure 1.

Analyzing the data of Figure 1, it should be noted that the share of agriculture in the country's GDP on average for the period under study amounted to $9.5 \%$ and in 2017 reached $11.8 \%$. 

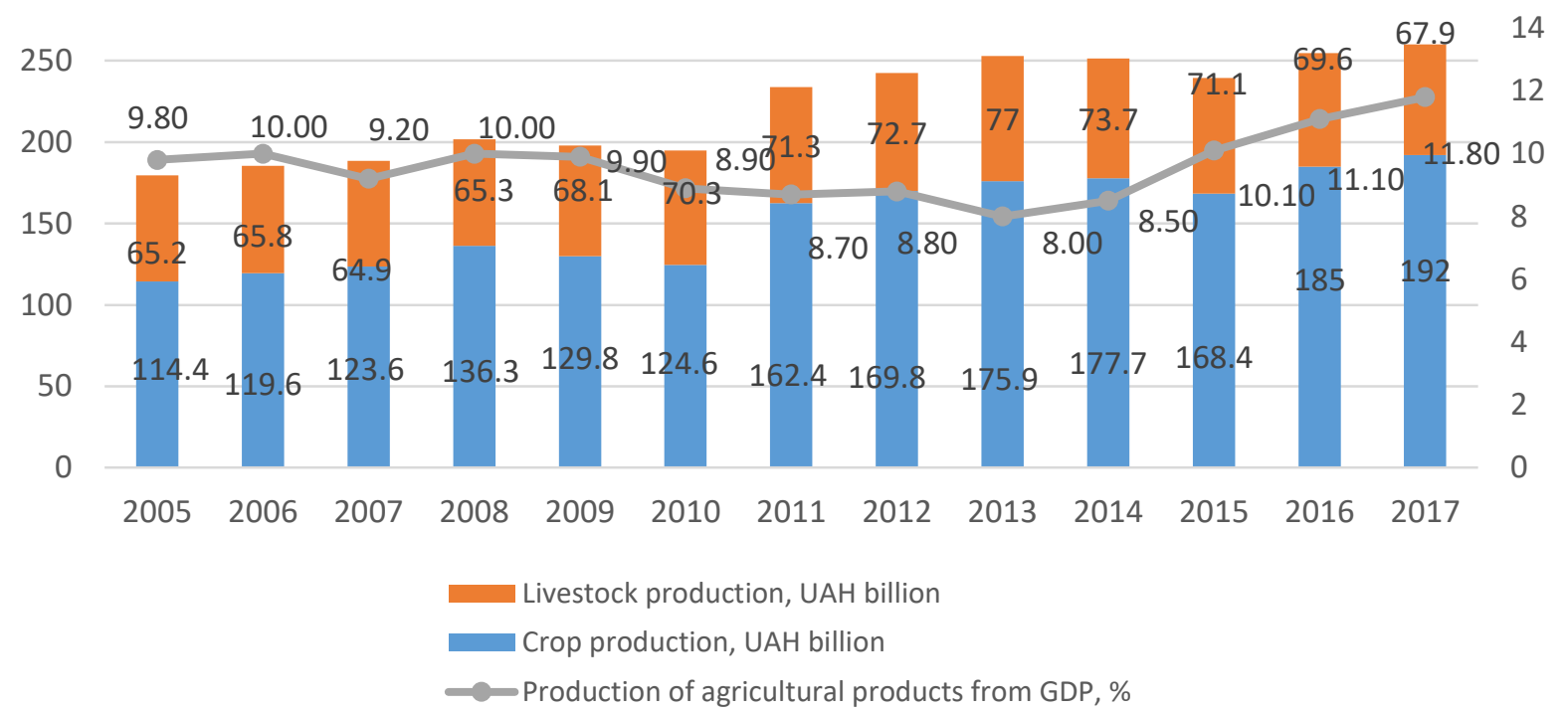

Figure 1. Production of agricultural products by sector and its share in GDP of Ukraine

In 2017, wholesale and retail trades dominate in the country's GDP structure accounting for $13.9 \%$ of the total GDP. The second is the processing industry $(12.0 \%$ of GDP) and the third place is agriculture, forestry and fisheries, which is $11.8 \%$ in the total GDP.

Considering the sectoral structure of agricultural production, it should be noted that the share of crop production prevails over the livestock production in its total volume. Thus, on average, during the investigated period (2005-2017), livestock production was only one third in the total amount of agricultural products. Correspondingly, the crop production provided about $70 \%$. Thus, the agricultural sector is one of the key branches and significant budget filling of Ukraine.

In addition, Ukraine was ranked among top ten exporters of agricultural products to the EU countries and ranks eighth. Figure 2 shows the top 10 most developed European countries in the field of agriculture. As can be seen from the data of the analyzed Figure 2, Ukraine has 8th position here.

It should be noted that Ukraine occupied leading positions in the world food market in 2017. In recent decades, our state is a confident exporter of grain, increasing its export potential. Among grain crops, the share of corn exports in 2017 is dominant (48\%), the share of wheat is $40 \%$ and barley $12 \%$, respectively. It should be noted that
Ukraine exports $3 / 4$ of produced corn and ranks third in the world in terms of its exports (only the USA and Argentina export more). In general, such corn exports in 2017 are record-breaking due to an increase in supplies to already developed markets and due to the opening of new ones (Iran 2.2 million tons and South Korea - 400 thousand tons) (Prokopchuk, 2017).

Thus, the agrarian sector is one of key and significant in filling budget of Ukraine and rather powerful exporter of agricultural products to the EU countries. Also, AIC is the main source of currency inflows into Ukraine and a key factor in maintaining trade balance.

\subsection{Features of insurance protection in the agrarian sector of the Ukrainian economy}

\subsubsection{General tendencies of agricultural insurance market}

Analyzing the general tendencies of the Ukrainian agricultural insurance market, it should be noted that over the last two years (2016-2017), there has been an increase in individual indicators and an increase in collected premiums.

In 2016, the studied market showed some recovery (breaking the long-lasting trend of contraction 


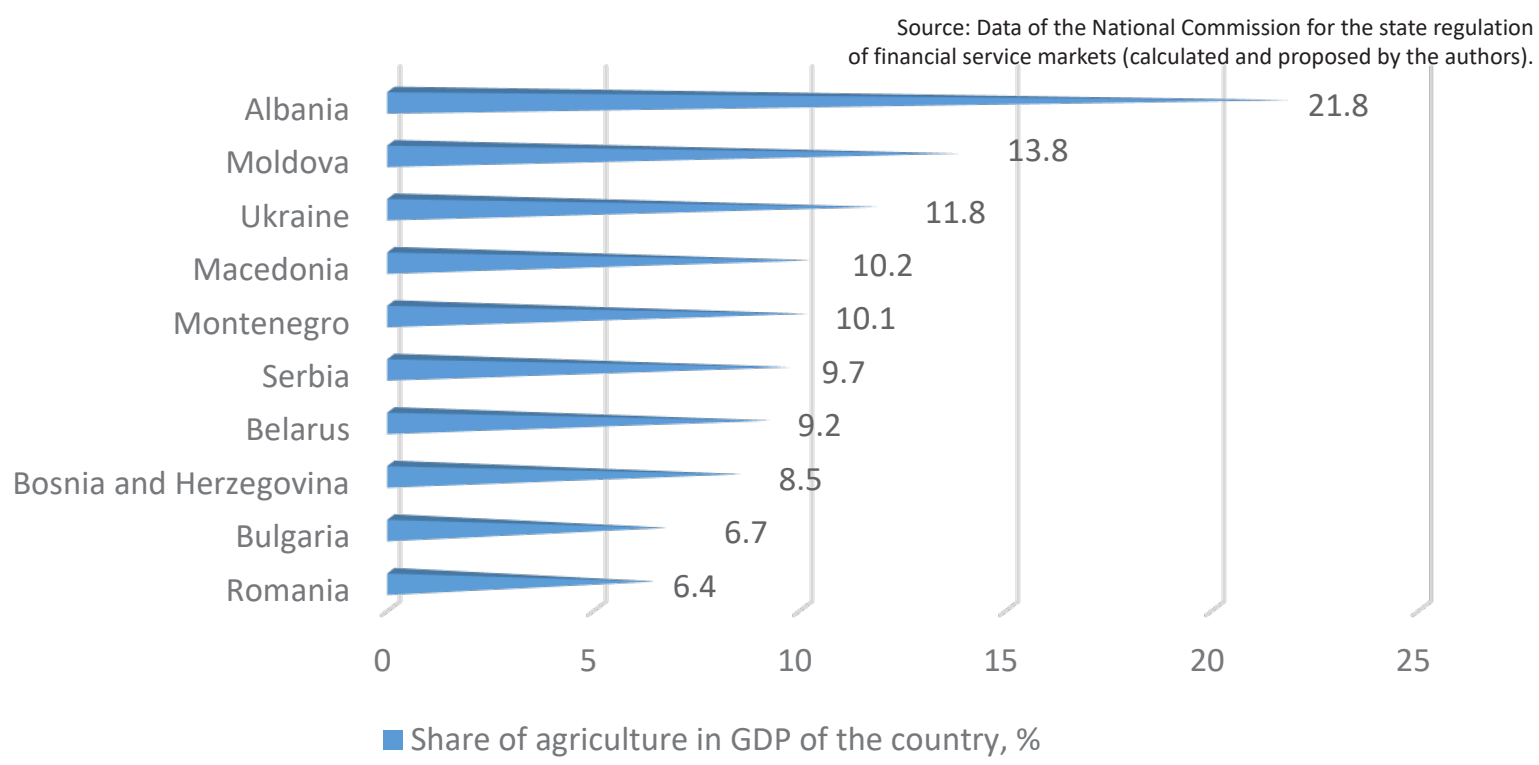

Figure 2. Share of agriculture in GDP of the most developed European countries in the field of agricultural production (in 2017)

and stagnation) and, in 2017, continued a positive trend towards growth in the context of a significant number of indicators (Figure 3). In 2017, for the first time since 2011, the number of concluded insurance contracts increased (growth was by $21 \%)$. Such indicator as the volume of collected insurance premiums has been increasing for the third year. In particular, in 2017, it grew by $30 \%$ and amounted to UAH 204.4 million. The average rate of the premium by 1 percentage point and the payment level for the winter period exceeds the indicator in 2016 by 8.5 percentage points.

Summing up 2017 underwriting year, it should be noted that the number of concluded insurance contracts for agricultural crops and perennial plantations by insurance companies has reached the level of 957, which, in the context of seasonal gradation, is 427 in winter and 530 in spring and summer, respectively. The size of the total insured sum reached UAH 5,913 billion, which is 5\% less compared with last year's value.

Insurance premiums collected by insurance companies totaled UAH 204.4 million, which exceeds the level of 2016 by $30 \%$ (Figure 3). The insurance area of agricultural crops was 657.1 thousand hectares. As for the average rate of the insurance premium, its size was 3.5\% (based on the results of 2017 underwriting year), exceeding the average annual level by $0.2 \%$ during the winter period
(3.7\%) and not reaching it by $0.1 \%$ (3.4\%) during the spring-summer period.

Analyzing the weather conditions of 2017 underwriting year, the following positions should be highlighted, which became key ones in case of occurrence of insurance cases and payment of reimbursements:

- fairly mild winter;

- $\quad$ sharp April frosts (up to $-5^{\circ} \mathrm{C}$ );

- $\quad$ arid second half of spring and summer with insufficient amount of precipitation, droughts and decrease in productive moisture reserve, which adversely affects winter and spring crops;

- hurricanes with strong wind, squalls, showers, local hail and, in some areas, tornadoes in summer.

\subsubsection{Agricultural insurance system in the context of agricultural crops}

In 2017 underwriting year, the insurance of 16 types of agricultural crops was carried out. Compared to 2016, the number of insured crops remained stable, but insignificant changes occurred in the structure of insured crops: there were no insurance contracts for pumpkins and 
Source: Data of the National Commission for the state regulation of financial service markets (calculated and proposed by the authors). 204.4

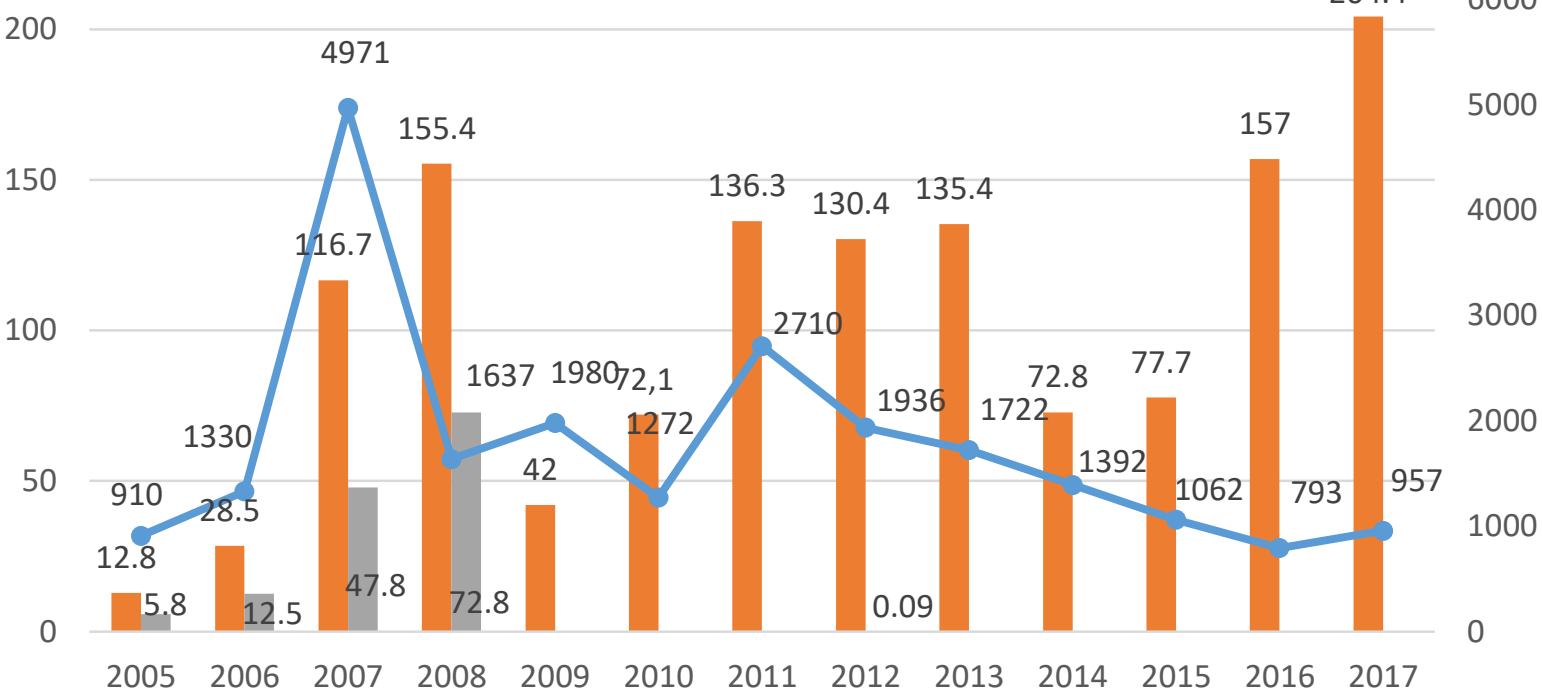

Amount of the premium, UAH million Subsidy, UAH million - Number of agreements

Figure 3. Main tendencies of the Ukrainian agricultural business market in the period 2005-2017

flax and, on the contrary, sorghum and rye were insured. Indicators of insurance in 2017 are shown in Table 1.

As can be seen from the data in Table 1, the largest number of contracts was concluded for winter wheat insurance (453 contracts or $47.3 \%$ ).
Information on payments in respect of crops is presented in Figure 4.

In 2017 underwriting year, insurance payments were made for 3 crops: winter rape $(58.7 \%$ of the total payments), winter wheat (39.0\%) and winter rye $(2.2 \%)$.

Table 1. Consolidated insurance data in the context of agricultural crops, 2017

Source: Analytical study "Ukrainian Agribusiness Market in 2005-2017", IFC Project "Development of Financing for the Agrarian Sector in Europe and Central Asia" (summarized, calculated and presented by the authors).

\begin{tabular}{|c|c|c|c|c|c|c|}
\hline Crop & $\begin{array}{l}\text { Number of } \\
\text { agreements }\end{array}$ & Area, ha & $\begin{array}{c}\text { Amount of } \\
\text { insurance, } \\
\text { thousand UAH }\end{array}$ & $\begin{array}{l}\text { Amount of } \\
\text { premiums, } \\
\text { thousand } \\
\text { UAH }\end{array}$ & $\begin{array}{l}\text { Average } \\
\text { premium } \\
\text { rate, \% }\end{array}$ & $\begin{array}{l}\text { Amount of } \\
\text { premiums, } \\
\text { UAH / ha }\end{array}$ \\
\hline Winter wheat & 453 & 414538 & 3142993.0 & 111880.9 & 3.6 & 270 \\
\hline Winter rape & 241 & 95401 & 396643.9 & 12051.9 & 3.0 & 126 \\
\hline Corn & 89 & 70209 & 1529975.0 & 61328.1 & 4.0 & 874 \\
\hline Sunflower & 61 & 36747 & 374017.7 & 5294.2 & 1.4 & 144 \\
\hline Winter barley & 24 & 9417 & 40381.2 & 1457.1 & 3.6 & 155 \\
\hline Soy & 21 & 7139 & 112515.5 & 2379.9 & 2.1 & 333 \\
\hline Winter rye & 20 & 5866 & 32701.2 & 1091.4 & 3.3 & 186 \\
\hline Spring barley & 13 & 3661 & 54851,2 & 851.8 & 1.6 & 233 \\
\hline Sugar beet & 11 & 4790 & 119955.9 & 6082.8 & 5.1 & 1270 \\
\hline Peas & 11 & 3632 & 22921.2 & 564.9 & 2.5 & 156 \\
\hline Spring wheat & 6 & 2841 & 23488.2 & 537.2 & 2.3 & 189 \\
\hline Sorghum & 2 & 1107 & 6304.4 & 131 & 2.1 & 119 \\
\hline Buckwheat & 2 & 215 & 2313.8 & 104.5 & 4.5 & 486 \\
\hline Beans & 1 & 1403 & 48698.3 & 633.1 & 1.3 & 451 \\
\hline Spring rye & 1 & 136 & 505.4 & 32.9 & 6.5 & 242 \\
\hline Vegetables, garden & 1 & 43 & 5100 & 24.2 & 0.5 & 565 \\
\hline Total & 957 & 657144 & 5913366.1 & 204446.9 & 3.5 & 311 \\
\hline
\end{tabular}




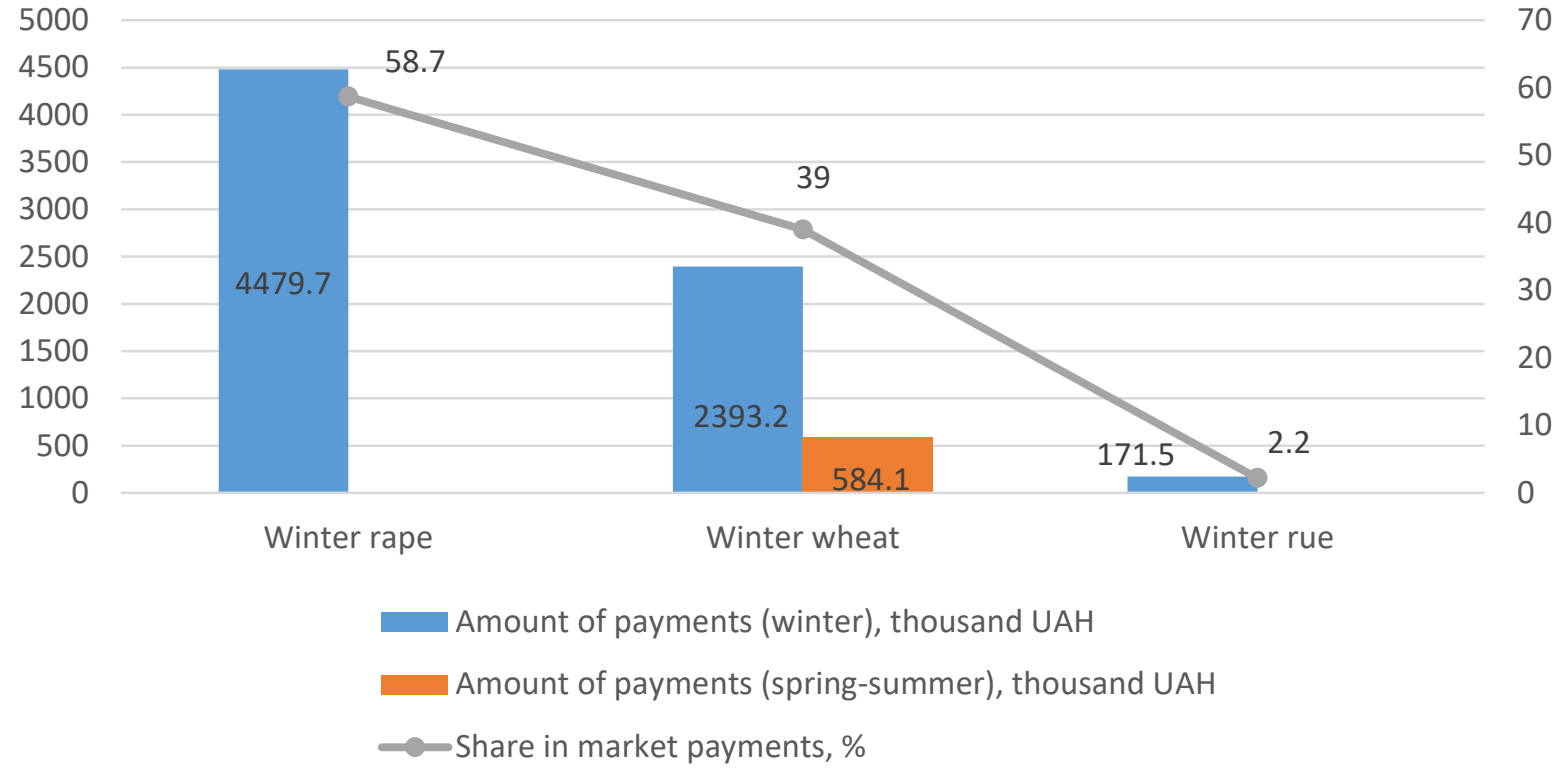

Figure 4. Insurance payments in the context of agricultural crops and seasonal gradation, 2017

\subsubsection{Agricultural insurance system in the context of animal insurance}

In 2017, 23 insurance contracts were concluded for animal insurance ( 13 for cattle, 9 for pig insurance and 1 for poultry insurance). The total insured amount was UAH 316 million and paid insurance premium was UAH 2.4 million. There were no claims for insurance indemnity and, consequently, insurance payments. The average rate of the insurance premium under concluded contracts is $0.8 \%$ (Figure 5). The low rate of insurance premium under animal insurance contracts indicates that these contracts do not cover main risks of livestock production.
Consequently, it should be noted that animals were used as collateral to obtain a loan in concluded contracts. Thus, animal insurance was formal in obtaining a loan or in other situations where the conclusion of an insurance contract is a condition for other transactions.

\subsubsection{Agricultural insurance system in the context of insurance products}

Ukraine has a great potential for the development of agrarian insurance. Today, insurance protection in the agrarian sector of the Ukrainian economy is carried out through a combination of traditional insurance products (Figure 6).

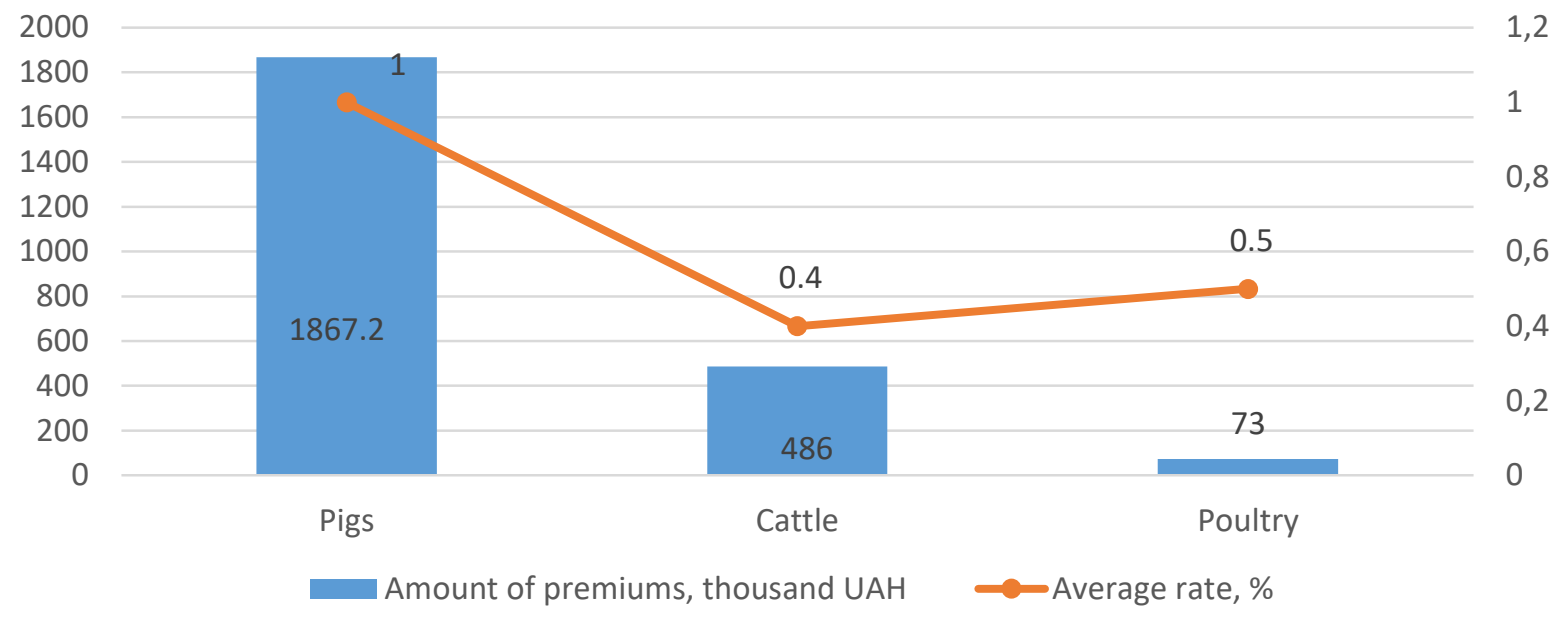

Figure 5. Data on animal insurance in 2017 


\section{INSURANCE PRODUCTS}

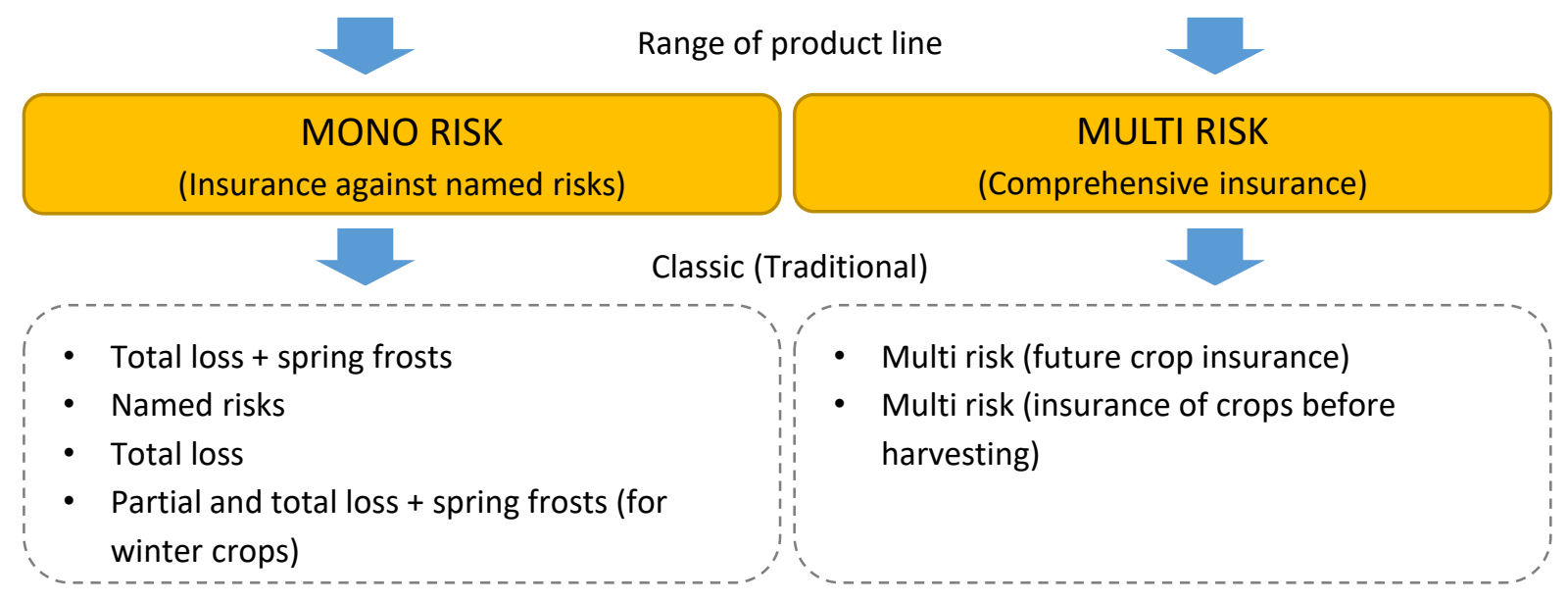

Figure 6. Types of insurance products offered

in the Ukrainian agricultural insurance market in 2017

Traditionally, the Ukrainian farmers favor crop insurance of winter crops and winter rape for the winter period, which by the number of contracts is $45 \%$ and $51 \%$ of the area. However, given the low cost of winter insurance, the insurance of the future harvest under the multi risk insurance program for the spring-summer period collected $77 \%$ of the amount of premiums in 2017.

Summarizing the above, it should be noted that in the Ukrainian agricultural insurance market, classical insurance products are presented in the context of mono and multi-risk insurance with their extensive product line. Index insurance products (based on yield, income, weather and vegetation indices) are innovative insurance products in the domestic agricultural insurance market. So, in particular, weather index products in Ukraine are in the stage of development and implementation and they are rather new kind of insurance products. They allow us relatively simply to determine the damage from effects of adverse weather events in the cultivation of various crops. In the world practice, index schemes of insurance have become widespread and have long been operating on the agricultural insurance market of different countries with an extensive product line of index insurance products.

Summarizing the above, it should be noted that rather powerful development of the agricultural and industrial complex in Ukraine is accompanied by insufficiently developed insurance coverage of the latter.

The above situation in which the agricultural sector develops at an accelerated pace and the volume of insured products is not increasing is often explained by the fact that the Ukrainian market of agricultural insurance services does not have a strategy for the development of the industry and the resource that was built up in previous years has expired and requires urgent renewal.

\subsection{Problems of development of the Ukrainian agrarian insurance system}

Analyzing the reasons for the rather weak development of the agricultural business market in Ukraine, the first of these is to highlight the issue of trust. The sale of insurance services in Ukraine is mainly carried out in a direct way, that is, directly by insurance companies of a closed or open type. It should be noted that on the Ukrainian insurance market over the period under study, there were about 400 insurance companies (Figure 7). Among them, only about 24 companies (or 6\%) were engaged in insurance activities in agriculture.

At the same time, it should be noted that many of them have a negative reputation, which eventu- 


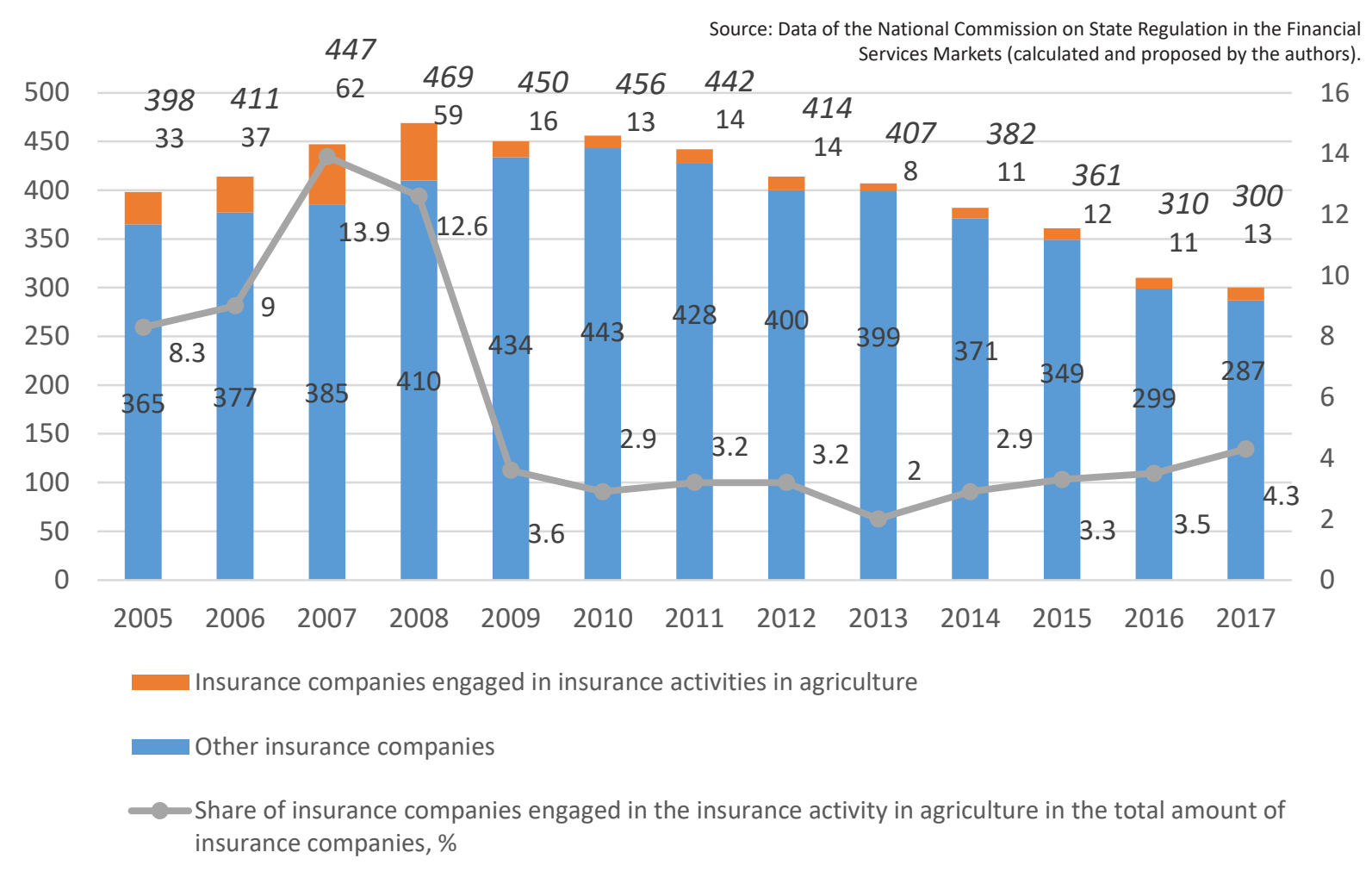

Figure 7. Number (units) and share (\%) of insurance companies in the Ukrainian agricultural insurance market

ally imposes a shadow on the entire sector. If we consider the insurance industry with an emphasis on the agricultural and industrial complex, the situation is a bit better, since on average $70-80 \%$ of risks are reinsured by international reinsurers. Reinsurers are large companies that hedge at the global level risks from Ukraine, the United States, India, China and other countries. When the time comes for payment, they cover most of the amount for the insurance company so that they can pay the client (about 80\%).

The second reason is the perception of the agricultural insurance system in Ukraine to greater extent as a separate and individual instrument.

This leads to the fact that only about $3 \%$ of all sown areas (average 26.8 million hectares during the investigated period) are insured (Figure 8 ).

Analyzing the data of Figure 8, it should be noted that on average for the investigated period (in the period 2005-2017) in Ukraine, only 3.1\% of sown area is insured. Moreover, this indicator of the maximum value at the level of $9.7 \%$ reached in 2007 (2,360 thousand hectares) and 4.3\% (1,717 thousand hectares) in 2008. Such increase of the analyzed indicator at this time interval is quite predictable, because in the period 2005-2008, the Ukrainian market of agricultural insurance functioned within the framework of the state support program under the condition of compulsory insurance. Instead, the size of the insured area was the lowest in 2005 (390 thousand hectares) and in 2009 (510 thousand hectares).

\subsection{Prospects of development of the Ukrainian agrarian insurance system}

The current state of the development of the agrarian insurance system in Ukraine does not correspond to its primary objective - to be an effective mechanism for risk management in the agricultural sector and ensure the stability of production and incomes of agricultural producers.

Today, the agrarian sector in Ukraine is actively developing. The agricultural sector is one of the key and significant filling items of the Ukrainian budget and a very powerful exporter of agricultural products to the European Union. Agricultural 


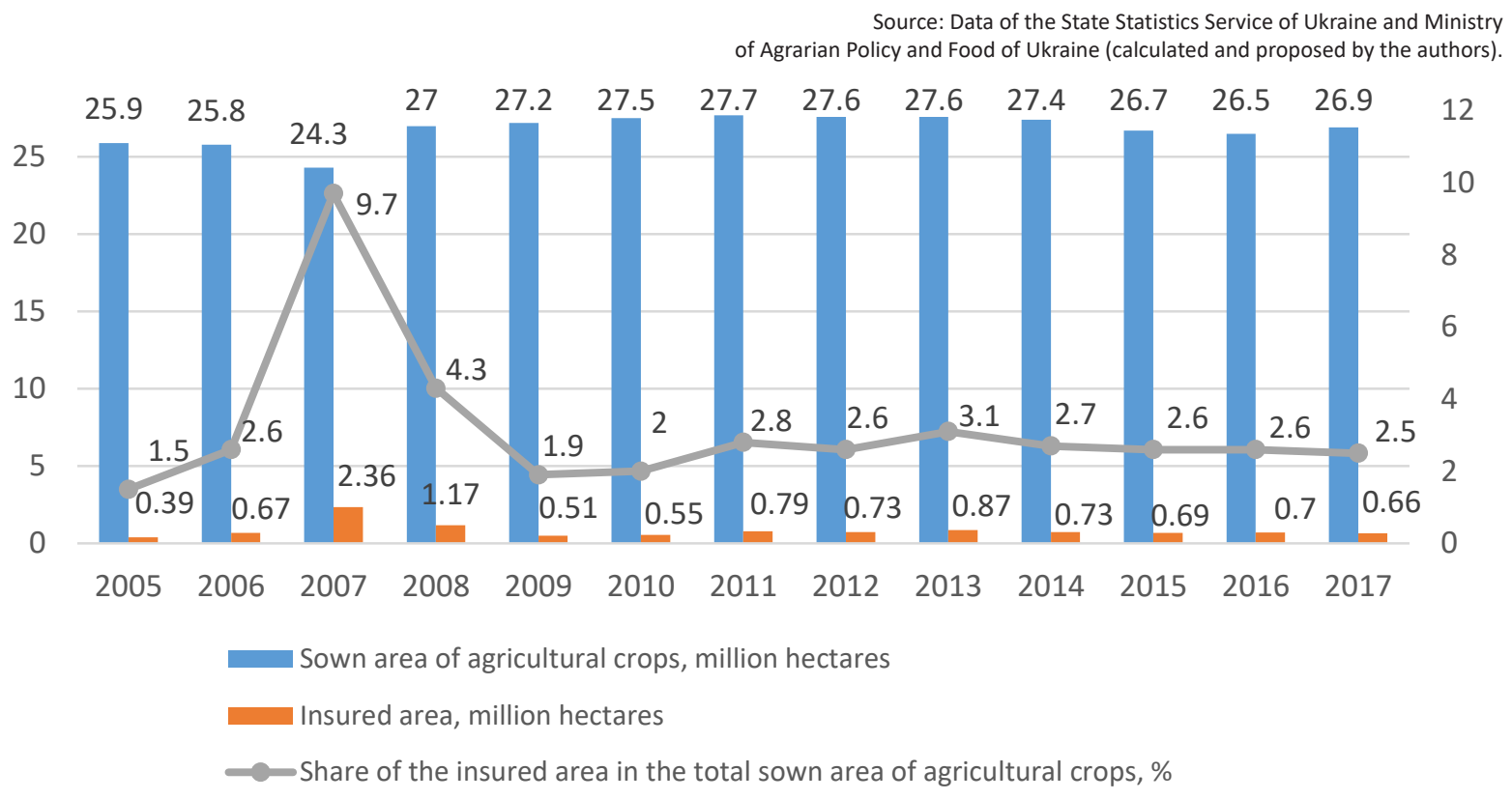

Figure 8. The share of the insured area in the total crop area of agricultural crops in Ukraine in the period 2005-2017

insurance is one of the mechanisms of its stable work and strengthening of small and medium agrarian businesses. Dominants of agricultural insurance direction for various entities are shown in Figure 9. For this, a strategy for the development of the agrarian insurance system should be developed in Ukraine, which should take into account the needs of all market participants.

The strategy for developing the agrarian insurance system should be based on the following key principles:

1) promotion of the agrarian sector of the economy;

2) improvement of the legislative framework of Ukraine in terms of regulating processes for providing insurance services to the agrarian market and providing state agricultural support to agricultural producers with agricultural risk insurance;

3) institutional development oriented and aimed at strengthening the state's ability to perform functions in this system;

4) consolidation of the insurance sector aimed at strengthening its ability to provide qualified services to the agrarian sector of the economy.
The system of agrarian risk insurance includes four key elements (participants):

1) producers of agricultural products, their associations - users of insurance services;

2) insurance organizations, their associations (in the form of a pool) - developers and providers of insurance services;

3) government - the implementer of the state policy on stabilization of agricultural production and income of producers;

4) auxiliary organizations (professional and community associations, expert legal structures and state institutions) - auxiliary service providers.

Interests and capabilities of system participants are crucial in developing the interaction between them:

- agricultural producers are in need of insurance protection, at the same time they are interested in reducing the cost of insurance products and expanding their range;

- insurance companies are prioritizing profit from operating in the agrarian market, but 


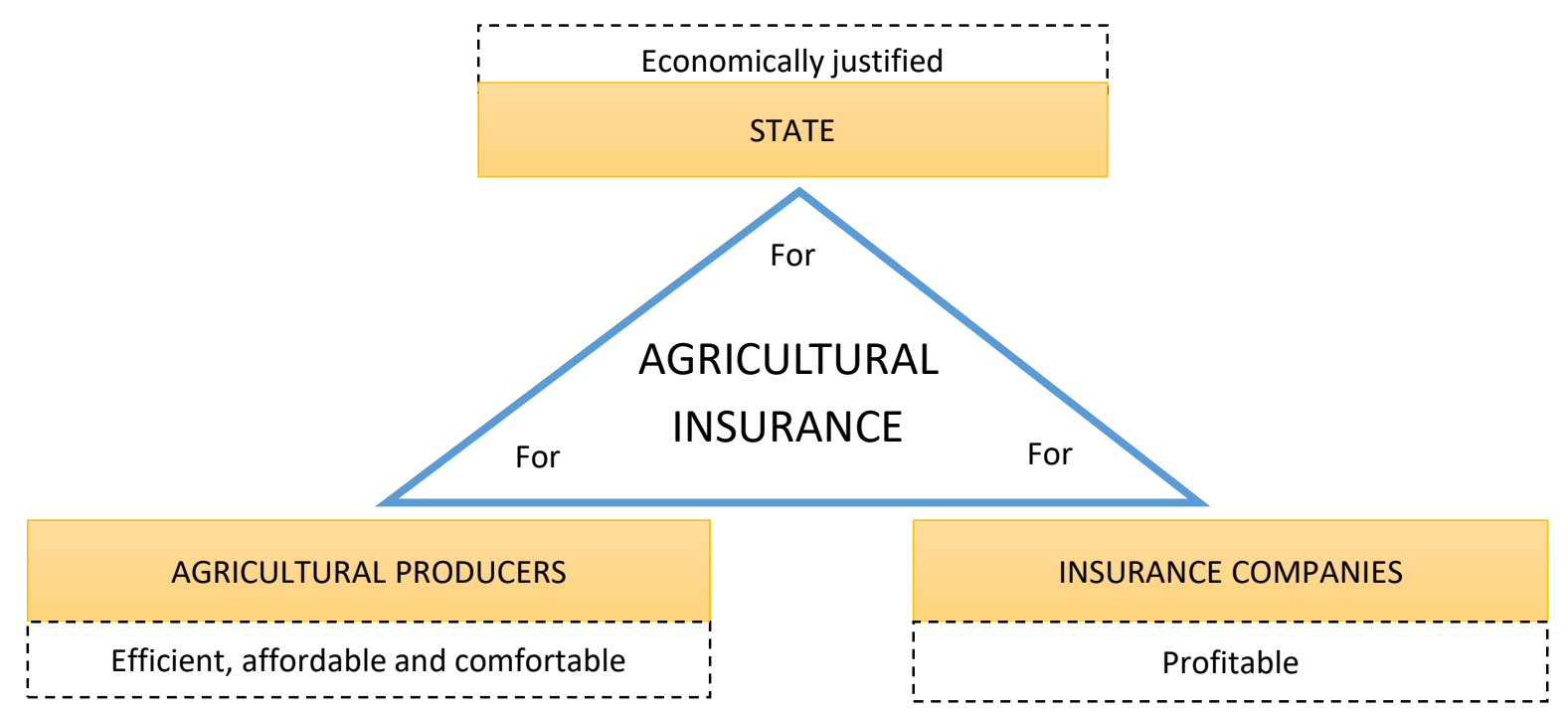

Note: Authors' generalization.

Figure 9. Dominates of the agricultural insurance direction for different entities

their abilities to obtain analytical information on the functioning of the market are limited;

- the government pursues the goal of stabilizing agricultural production and agricultural producers' incomes, but state resources provided for these purposes are rather limited.

The central role in the agricultural insurance system should belong to the government, which implements the state policy in support of agricultural insurance and creates conditions for coordination of interests of other participants of the system and, accordingly, consolidation of their efforts, orienting them towards achieving the key goal of the system's development.

Referring to the international practice, it should be noted that, in most countries, agricultural business development is comprehensively supported at the state level and the agricultural insurance tool is considered as one of effective tools for the stability of the agrarian sector of the economy as a whole, not just certain companies.

It should be emphasized that in countries where the government does not pay attention to agricultural insurance, its development is slow and unsystematic. As a rule, interested states in the restoration of agricultural production to provide insurance protection for agricultural producers and stabilizing their income over time, support agri- cultural insurance. Moreover, in practice of different countries, three basic models of state regulation of insurance protection in the agrarian sector of the economy are used (Figure 10).

The model of public-private partnership is the most balanced model, both from the standpoint of state support for agricultural insurance and effective cooperation between public and private sectors.

Today, in the international practice of agricultural insurance, five types of models of state support and private-public partnership can be distinguished (Figure 11).

In the United States, a state-supported agricultural insurance model is considered one of the best examples in the international practice. Models of agricultural insurance pools in Spain and Turkey are also worthy of attention. In Canada, the interaction between insurance companies and the state in the field of agricultural insurance has its differences. At the same time, the partnership model built there for several decades proves its effectiveness.

Thus, generalizing international practice, it should be noted that the most effective form of support for agricultural insurance is to reduce the cost of insurance premiums for agricultural producers through the provision of subsidies and simultaneous provision of state reinsurance of risks. 


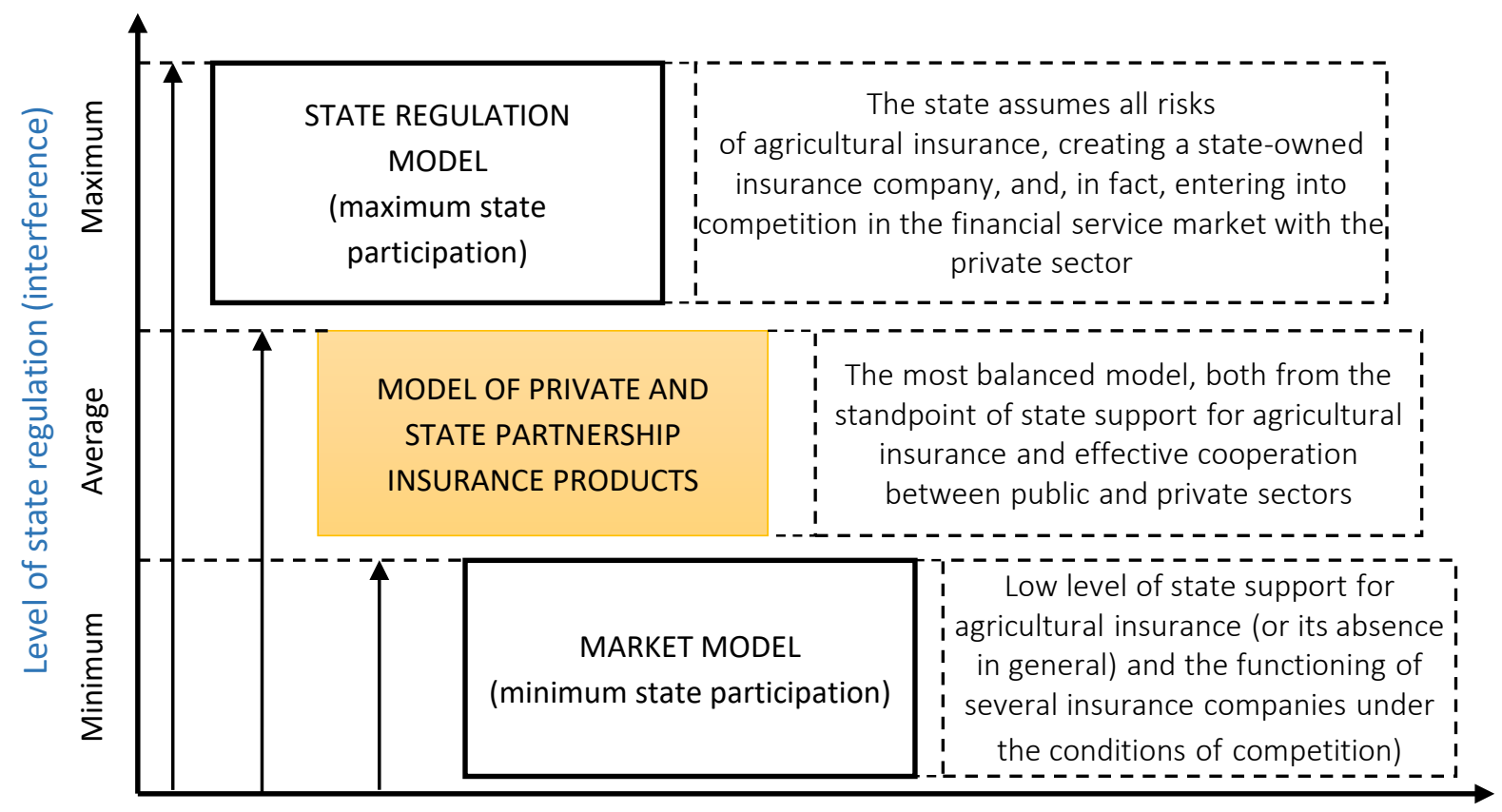

Participants and the form of cooperation on the agricultural insurance market

Note: Authors' generalization.

Figure 10. Models of state regulation of insurance protection in the agrarian sector of the economy

\section{MODELS OF STATE SUPPORT AND PRIVATE-PUBLIC PARTNERSHIP}

\begin{tabular}{|c|c|}
\hline \multicolumn{2}{|r|}{ Model type } \\
\hline I & A high-efficiency private-public partnership model \\
\hline II & A model with a dominant influence of the state \\
\hline III & A model of agricultural insurance through insurance pool \\
\hline IV & $\begin{array}{c}\text { A model of functioning on the market } \\
\text { of a "single" agricultural insurer }\end{array}$ \\
\hline V & $\begin{array}{l}\text { A modal of the minimum participation } \\
\text { of the state in the system of agri-insurance }\end{array}$ \\
\hline
\end{tabular}

Country of operation

The USA

Canada, Israel

Spain, Turkey

Austria, Switzerland

Germany

Note: Authors' generalization.

Figure 11. Typical characteristics of state support models and private-public partnerships operating in international practice 
The application of such an approach to the organization of state support to agricultural insurance, in contrast to the system of direct catastrophic payments, makes it possible to employ market mechanisms for achieving social goals and as a result:

- to use budget funds more efficiently;

- to involve agricultural production producers in risk management;

- to encourage agricultural production producers to comply with and apply the best production technologies; to promote the development and consolidation of the insurance sector;

- to promote development of the agrarian sector of the economy as a whole and stabilization of agricultural producer incomes, in particular.

In our opinion, further construction of an efficient and effective agricultural insurance system in Ukraine should take place within the framework of the model of private-public partnership, which is proved by positive international experience, which represents the balance of cooperation between public and private sectors.

\section{CONCLUSION}

The research of the current state, general trends and prospects for the development of the Ukrainian agricultural insurance system has allowed us to formulate the following conclusions:

1. At this stage, agrarian insurance in Ukraine does not fulfill its key objectives, in particular, on the one hand, as a factor that minimizes risks associated with the most unpredictable factor (the weather) and the other, as a way of managing the financial risks of agricultural enterprises, which ensures stability and predictability of their working capital, without which the functioning of agribusiness is impossible.

2. The agrarian insurance market of Ukraine is represented only by a system of insurance of agricultural crops and perennial plantations (the dominance of field crop insurance). Instead, the animal insurance system was used only as a formal tool for other purposes, in particular, as an auxiliary measure for obtaining a bank loan.

3. According to the results of the study, characteristic features of the current state of the Ukrainian agricultural insurance system development are summarized. They include: unpopularity of insurance among agricultural producers; limited offer of a specific set of insurance products offered by insurance companies on the Ukrainian agricultural insurance market; lack of support for the development of the agricultural insurance system at the state level.

4. It is established that at this stage the Ukrainian agricultural insurance market overcomes the difficult way of formation and development. It is evidently confirmed by the accelerated pace of development of the domestic agricultural sector and constant insignificant volumes of insured products due to the lack of a strategy for market development in general.

5. According to the results of the study, prospects for further development of the Ukrainian agrarian insurance system based on the development of the strategy of the latter, with the maximum consideration of needs and interests of all its participants, are shown.

6. It is determined that the strategy of development of the Ukrainian agrarian insurance system should be based on a set of principles. They include: promotion of the agrarian sector of the economy; improvement of the legislative framework of Ukraine (in particular, in terms of regulating processes of providing insurance services to the agrarian market and providing agricultural producers 
with state support for agricultural risk insurance); institutional development (oriented and aimed at strengthening the state's ability to perform functions in this system); consolidation of the insurance sector, aimed at strengthening its ability to provide qualified services to the agrarian sector of the economy.

7. Further development of an effective and efficient agricultural insurance system in Ukraine should take place within the framework of a private-public partnership model, as proven by the positive international experience that embodies the balance between public-private partnerships.

The implementation of the measures proposed in the framework of the strategy for the development of the Ukrainian agrarian insurance system through the effective use of state resources and maximum utilization of opportunities of the agricultural market and the insurance market must ensure stability of both agricultural production in general and incomes of rural population in particular, which are necessary prerequisites for stable economic growth of the country and welfare of its citizens.

\section{REFERENCES}

1. Ahmed, O., \& Serra, T. (2014). Economic analysis of the introduction of agricultural revenue insurance contracts in Spain using statistical copulas. Agricultural Economics, 46(1), 69-79. https:// doi.org/10.1111/agec.12141

2. Ahsan, S. M., Ali, A. A., \& Kurian, N. J. (1982). Toward a theory of agricultural insurance. American Journal of Agricultural Economics, 64(3), 510-529.

3. Bogale, A. (2015). Weatherindexed insurance: an elusive or achievable adaptation strategy to climate variability and change for smallholder farmers in Ethiopia. Climate and Development, 7(3), 246-256. https://doi.org/10.1080/1 7565529.2014.934769

4. Enjolras, G., \& Sentis, P. (2011). Crop insurance policies and purchases in France. Agricultural Economics, 42(4), 475-486. https://doi.org/10.1111/j.15740862.2011.00535.X

5. Finger, R., \& Lehmann, N. (2012). The influence of direct payments on farmers' hail insurance decisions. Agricultural Economics, 43(3), 343-354. https://doi.org/10.1111/j.15740862.2012.00587.x

6. Fuchs, A., \& Wolff, H. (2011). Concept and Unintended Consequences of Weather Index Insurance; The Case of Mexico. American Journal of Agricultural
Economics, 93(2), 505-511. https:// doi.org/10.1093/ajae/aaq137

7. Hazell, P. B. (1992). The appropriate role of agricultural insurance in developing countries. Journal of International Development, 4(6), 567-581.

8. Kenderdine, T. (2018). Insurance Plus Futures: Agricultural Commodity Price Reform in China. Asia and the Pacific Policy Studies, 5(2), 331-346. https://doi. org/10.1002/app5.226

9. Martseniuk-Rozaronova, O. V. (2010). Державна підтримка при страхуванні сільськогосподарських товаровиробників [Derzhavna pidtrymka pry strakhuvanni silskohospodarskykh tovarovyrobnykiv]. Ekonomika APK, 10, 91-95.

10. Mclntosh, C., Sarris, A., \& Papadopoulos, F. (2013). Productivity, credit, risk, and the demand for weather index insurance in smallholder agriculture in Ethiopia. Agricultural Economics, 44(4-5), 399-417. https://doi.org/10.1111/ agec. 12024

11. Mentel, G., \& Brożyna, J. (2015). Compatibility of market risk measures. Journal of International Studies, 8(2), 52-62.

12. Meza, F. J., Hansen, J. W., Osgood, D. E. (2008). Economic value of seasonal climate forecasts for agriculture: Review of ex-ante assess- ments and recommendations for future research. Journal of Applied Meteorology and Climatology, 47, 1269-1286.

13. Müller, B., Johnson, L., \& Kreuer, D. (2017). Maladaptive outcomes of climate insurance in agriculture. Global Environmental Change, 46, 23-33. https://doi.org/10.1016/j. gloenvcha.2017.06.010

14. Navrotskyi, S. A. (2012). Стан та тенденції розвитку сільськогосподарського страхування [Stan ta tendentsii rozvytku silskohospodarskoho strakhuvannia]. Nauka y ekonomika, 1(25), 61-68.

15. Nedbaieva, S. M. (2009). Державне регулювання страхуванням сільськогосподарських ризиків [Derzhavne rehuliuvannia strakhuvanniam silskohospodarskykh ryzykiv]. Investytsii: praktyka ta dosvid, 24, 88-91.

16. Panda, A. (2013). Climate Variability and the Role of Access to Crop Insurance as a Social-Protection Measure: Insights from India. Development Policy Review, 31(2), 57-73. https://doi.org/10.1111/ dpr.12039

17. Polchanov, A. Iu. (2013). Агрострахування як складова продовольчої безпеки держави [Ahrostrakhuvannia yak skladova prodovolchoi bezpeky derzhavy]. Visnyk Kyivskoho natsionalnoho 
torhovelno-ekonomichnoho universytetu, 4, 48-57.

18. Prokopchuk, O. T. (2017). Сучасний стан та тенденції розвитку системи страхування сільськогосподарських культур в Україні [Suchasnyi stan ta tendentsii rozvytku systemy strakhuvannia silskohospodarskykh kultur $\mathrm{v}$ Ukraini]. Zbirnyk naukovykh prats Umanskoho natsionalnoho universytetu sadivnytstva, 91(2), 86-100.

19. Prokopchuk, O. T., Ulianych, Yu. V., Bechko, V. P. (2014). Особливості страхування аграрних ризиків у країнах світу [Osoblyvosti strakhuvannia ahrarnykh ryzykiv u krainakh svitu]. Aktualni problemy ekonomiky, 3(153), 46-53.

20. Sakhno, O. V. (2010).

Агрострахування в Україні: сучасний стан, проблеми та перспективи [Ahrostrakhuvannia v Ukraini: suchasnyi stan, problemy ta perspektyvy]. Ekonomika $A P K, 9,14-16$.

21. Sakhno, O. V. (2010). Агрострахування як інструмент управління ризиками в агропромисловому комплексі України [Ahrostrakhuvannia yak instrument upravlinnia ryzykamy $\mathrm{v}$ ahropromyslovomu kompleksi Ukrainy]. Ekonomika APK, 10, 12-15.

22. Sarris, A. (2013). Weather index insurance for agricultural development: Introduction and overview. Agricultural Economics, 44(4-5), 381-384. https://doi.org/10.1111/ agec.12022

23. Shen, Z., \& Odening, M. (2013). Coping with systemic risk in index-based crop insurance. $A g$ ricultural Economics, 44(1), 1-13. https://doi.org/10.1111/j.15740862.2012.00625.x

24. Shi, H., \& Jiang, Z. (2016). The efficiency of composite weather index insurance in hedging rice yield risk: evidence from China. Agricultural Economics, 47(3), 319-328. https:// doi.org/10.1111/agec.12232

25. Sholoiko, A. S. (2013). Світовий досвід державної підтримки сільського господарства через програми страхування. [Svitovyi dosvid derzhavnoi pidtrymky silskoho hospodarstva cherez prohramy strakhuvannia]. Visnyk KNU imeni Tarasa Shevchenka, $135,41-43$
26. Skees, J. R., Barnett, B. J., \& Murphy, A. G. (2008). Creating insurance markets for natural disaster risk in lower income countries: The potential role for securitization. Agricultural Finance Review, 68, 151-167.

27. Streimikiene, D., Balezentis, T., \& Krisciukaitiene, I. (2016). Benefit of the Doubt Model for Financial Risk Analysis of Lithuanian Family Farms. Economics \& Sociology, 9(1), 6068. https://doi.org/10.14254/2071789X.2016/9-1/4

28. Takahashi, K., Ikegami, M., Sheahan, M., \& Barrett, C. B. (2016). Experimental evidence on the drivers of index-based livestock insurance demand in Southern Ethiopia. World Development, 78, 324-340. https://doi.org/10.1016/j.worlddev.2015.10.039

29. Weber, R., Fecke, W., Moeller, I., $\&$ Musshoff, O. (2015). Mesolevel weather index insurance. Agricultural Finance Review, 75(1), 31-46. https://doi.org/10.1108/ AFR-12-2014-0045 